at Brookwood, has been appointed medical superintendent of the new Surrey County Asylum at Netherne, near Coulsdon.

Mr. Arthur Lister, F.R.S., F.L.S., who died on Sunday last, July 19th, at the age of 78 years, was the younger brother of Lord Lister, and the author of important work in connexion with the Mycetozoa.

\section{LATAH AND CRIME.}

By William Fletcher, M.B.Cantab., DISTRICT SURGEON, GENERAL HOSPITAL, KUATA LUMPUR, FEDERATED MALAY STATES.

IN his article on latah" ${ }^{1}$ Sir Patrick Manson says : "Fortunately examples in which latah has been shown to play a part in crime are rare or unknown. It is conceivable, however, that under the influence of suggestion an affected person might be induced to kill or commit some other crime. In such circumstances it might be difficult to assess or to fix responsibility." Chiefly with the object of determining whether an individual who is subject to this condition can always be held responsible for all his actions the following inquiry has been made. The condition known as latah is confined to the inhabitants of the Malay Peninsula, Java, Sumatra, and the islands of their vicinity.

I have not heard of any cases amongst Malays who have been established in other countries for any number of generations. There is a large colony of Malays in Ceylon. I made inquiries amongst these people and have been informed that the disease does not occur there. Sir Allen Perry, the principal civil medical officer of Cerlon, has heard of no cases of latah in that country. In the Malay Peninsula the disease affects the Malays almost exclusively but is also seen in persons of other nationalities who have mixed with them for many years. This applies especially to Chinese born in the country. In addition to Chinese, Tamils, Europeans, and other immigrants may become affected. As Mr. J. D. Gimlette points out, many semi-civilised communities are subject to psychoses of a like nature-e.g., the Ikota of the Samoyeds and the Tigretier of Abyssinia. Latah varies from a mere nervous "jumpy" condition, in which reaction to a sensory stimulus suddenly and unexpectedly perceived is exaggerated in degree, to a reaction which is abnormal not only in degree but also in type and which may be produced by merely a word, look, or gesture. In the mildest form the subject may only scream when startled, or more often will give vent to some exclamation. Generally the exclamatory reaction is coördinated into a sentence, often abusive, which may not be of a stereotyped nature. For instance, a European resident of Selangor, regardless of place or circumstances, would regularly shout out, "Go to hell," if startled by an unexpected stimulus, tactile or auditory. Frequently, if the exciting stimulus be auditory, the sound will be imitated. Should a motorist sound his horn on passing a bullock-cart containing a party of Malay ladies it is not uncommon for him to elicit an answering "Toot-toot" from at least one of them. The subject of the severer form of this psychosis may, under the strain of excitement, became quite incapable of answering any questions, or, indeed, of doing anything except mimic his interrogator.

Mr. Fleming, the district officer of Tampin, tells me that when he has been holding court in some of the Pahang districts he has found it quite impossible to examine the witnesses as they could do nothing but imitate and repeat the questions put to them. "It was only," he says, "by removing them from the witness-box, allowing them to squat down beside my chair, and talking quietly to them that I was able to elicit their evidence."

In its gravest form latah resembles the third or somnambulistic stage of hypnotism. I have not, however, been able to discover that suggestions made during the somnambulistic condition are carried out in the normal or waking state. There are, moreover, important differences with regard to "volition" which will be dealt with later. If the unfortunate individual affected with this most pronounced trpe be suddenly startled he may pass into a condition in which he is constrained to obey every suggestion put to him and is absolutely at the mercy of anyone who chooses to employ him as food for amusement. At first there is but slight suppression of normal consciousness and in the subsequent waking state all events that took place will be remembered, though frequently as if they had happened in a dream (macham memimpi). Should the "séance" be long continued the normal consciousness is suppressed and on waking the subject is amnesic to the events of the latah state. This condition of advanced somnambulism is usually followed by a profound sleep (lena) of several hours' duration.

The passivity of the latah condition and the ready response to suggestion are well illustrated by a story from Swettenham's "Malay Sketches," instanced by Manson, where a Malay climbed a cocoanut tree in obedience to the suggestion of a friend and remained at the top thereof for six hours during the hottest part of the day because a second comrade had twisted a rattan round the base of the tree and told him that he could not descend because the rattan was a snake. Latah is very common amongst the Malays and it is almost the exception to find a woman over 45 years of age who is not more or less subject to this condition. The subjects of latah, apart from the occurrence of its manifestations, are in no way different from their fellows. They are not persons of weak mind and, indeed, may be of marked personality.

At Grit in Upper Perak Mr. Berkeley, the district officer, tells me that there is a latah policeman who possesses so dominant a personal influence over the Malays of the neighbourhood that it is only necessary for him when effecting an arrest to suggest to his prisoner that he is powerless to escape to render it impossible for him to do so. Its onset is common at the age of puberty, but a native doctor named Wan Chee tells me that he has seen children whose parents are subject to it become latah at the age of six. The manifestations in children are usually of a mild type. It may commence at any age and its determining causes are the same as those of other neurotic states-e.g., childbirth, trouble, the climacteric. \&c. Once an individual has become the subject of latah he almost invariably remains so and tends to progress towards the graver form. This does not always happen. A- is a chauffeur; on his left arm there is an old scar the history of which is as follows. $\mathrm{He}$ was sitting in the door of his house trimming a piece of wood with a large clasp-knife when a small lizard fell from the roof on to his leg. He was startled into a condition of latah and raising his knife he drove it home into the muscles of his forearm. He has now sufficiently recovered from his peculiarity to drive a motor car. I cannot, however, believe that he does so without abnormal risk. The condition is undoubtedly contagious by imitation and this has given rise amongst the Malays to the idea that it is infectious and hereditary. A-_'s parents were latah, and he tells me the following story of his paternal grandparents who lived in Penang. One day his grandmother was startled by a large rat snake in the garden and was impelled by a latah impulse to seize it by the neck and hold on. Her husband hearing screams rushed out of the house, and finding his wife holding on to the neck of a big snake and unable to let go he was so startled that he too passed into a latah condition and in imitation of his wife caught hold of the snake by the tail. The rest of the family hearing the uproar came upon the scene just in time to see the old people pull the snake in half. Latah, as would be expected, is more common amongst women than men.

It is not looked upon as a disease by the Malays but as a personal peculiarity such as big feet, a long nose, or flopping ears, to be politely left unnoticed by acquaintances, and when occurring in people of position, but to be dwelt on and made use of as an instrument of castigation by near relatives, intimate friends, and enemies. The disease is not only confined to the uneducated. A short time ago 1 was talking with a Malay medical man on the subject. $\mathrm{He}$ is a man of more than average intelligence and has associated a good deal with Europeans. Whilst we were talking his wife, who was sitting at the other side of the table and listening to our conversaticn, suddenly struck the table and shouted, "What's the matter?" The doctor jumped. repeated her words, and then laughed sheepishly, ashamed to have betrayed himself.

The Malays themselves believe that "latah" is not confined to mankind but that sometimes animals are 
affected. Raja Alang Iskander of Perak tells me that long ago in an isolated house there lived a Malay with his wife and children. One night when the husband was absent at a distant village the woman went out of the house to draw a little water from the well. She did not return, and her children, too frightened to go out in search of her, were terrified by the roar of a tiger in the compound. At dawn the husband returned with some friends and a strange sight met their eyes. In the little brinjal patch at the back of the house the Malay woman and a large tiger were prowling round each other growling. Occasionally the tiger would make a little spring towards the woman and the woman would spring towards the tiger. Then she would jump back and the tiger would jump back too. Both the woman and the tiger were latah !

In being contagious by imitation latah resembles those epidemics of hysteria which sometimes take place " in small and predisposed societies such as schools, nunneries, remote and superstitious villages, and the phenomena are such as appeal strikingly to the imagination, such as religious ecstasies, strange forms of fits, saltatory spasms and laryngeal noises such as bellowings, barkings, or mewings."' As Manson points out these latter outbreaks occur in epidemics, whilst latah is an endemic psychosis. The former, he says, are diseases of the emotions, the latter of the intellectual reflexes. With regard to the somnambulistic stage of latah, "Janet considers somnambulism closely allied to hysteria and hysterical fits as virtually instances of somnambulism." It is especially in connexion with this somnambulistic stage of latah that the important question of volition arises.

With regard to volition in the hypnotic stage Dr. J. Milne Bramwell ${ }^{3}$ says: "I have never seen a hypnotic suggestion carried out which involved anything opposed to the patient's prejudices, feelings, or moral sense. Bernheim and others base the possibility of hypnotic crime on the fact that hypnotic subjects will sometimes execute imaginary ones, e.g., put a lump of sugar into a friend's teacup when told it is arsenic; questioning in subsequent hypnosis, however, always reveals the fact that the subject knew exactly what he was doing and fully recognised the experimental nature of the transaction." In the somnambulism of latah this is certainly not the case. There is at the present time a Malay woman in the General Hospital, Kuala Lumpur, whom I have seen constrained by suggestion to run her fingers repeatedly through her hair, ruffe it up, and pull it over her face just after she had completed her toilet and carefully arranged her hair. Soon afterwards when the poor woman had "done" her hair again the suggestion was repeated with the same result. This was, I am sure, "opposed to the patient's prejudices and feelings." It is a well-known fact that latah folk will strip off their clothing at the suggestion conveyed in a gesture. This is strongly opposed to their feelings. No Malays, not even the men, will ever bathe naked.

Mr. Wilkinson, secretary to the Resident for the State of Perak, tells me of a case which is interesting from a forensic point of view with regard to crime committed owing to a latah impulse but without the involvement of a criminal suggestion. It occurred some years ago in Malacca. 'Two men, who may be called Kassim and Amat, were walking together through the jungle, each carrying his parang, or heavy chopping knife, when a dead twig, breaking off from a tree overhanging the path, fell to the ground. Kassim, being startled by its fall, in imitation thereof flung himself down on to the path. His companion, Amat, in his turn being startled by seeing his friend fall to the ground and overcome by the imitative impulse, threw himself down on the track by the side of Kassim and in so doing swung round his arm and parang. The heavy parang struck Kassim on the wrist and completely severed his hand from the arm. Amat was arrested, in due course appeared before the magistrate, and was sent to gaol for six months. Kassim, the injured man, stated that he felt sure that the affair was an accident; he had lived for years in the same kampong with Amat; they were both latah and he entirely accepted Amat's explanation. The court, however, probably felt that it was impossible to admit the excuse of latah. The disease is so common that were such a precedent created any Malay on his trial for a deed of violence would plead latah as an excuse. A similar case is that of a Sikh who

2 J. A. Ormerod, Clifford Allbutt's System of Medicine, vol. viii. 3 Encyclopxedia Medica. was squatting down beneath a small bush by the side of a jungle path when a latah Malay happened to walk by. At the moment the latter was passing the Sikh rose up from the ground and his head appearing suddenly through the leaves of the bush so startled the Malay that he at once became latah, and thinking that the saw a wild beast before him split the head of the unfortunate Sikh with his parang. In both these cases grievous bodily hurt was inflicted owing to an uncontrolled impulse in a latah subject who had been startled by a sudden shock. The question now arises as to whether an individual who is latah will carry out a criminal action which is altogether due to the influence of a suggestion made by a second party and which would be repugnant to the individual when in a normal state. Most authorities on hypnotism deny the possibility of "hypnotic crime."

In order to investigate the question of "volition" with regard to crime in a person subject to pronounced latah the following experiment was carried out. A woman named $\mathrm{J}$ - was admitted to the General Hospital, Kuala Lumpur, suffering from sarcoma of the breast. She was very latah and said that she had been so since the death of one of her children which had taken place rather suddenly a few years ago and was a great shock to her. J_- was in a small room with two other Malays. This room communicated by a short passage with a ward in which there was a large number of Tamil patients. She could not see the ward from her bed in the little room. On the particular day on which the experiment was carried out there was a drizzling rain, and, as is their custom in such weather, the Tamil patients were curled up on their beds entirely covered by their blankets. One of these patients was aroused and sent out into the verandah. The outline of the body was then reproduced under the blanket by means of a pillow and a folded raincoat. The appearance was indistinguishable from that presented by the real patients as hidden under their blankets in the beds near. J__ was then sum. moned from her room and told that there was a rich Tamil woman covered with jewellery asleep on one of the beds. The bed with the raincoat was then pointed out to her. Suddenly a large amputating knife was thrust into her hands and a command was shouted at her, "Kill that woman and steal her jewellery." J- rushed at the bed and with great force drove the knife into the blanket and the raincoat underneath. Hardly had she struck before she uttered a cry of remorse and threw herself back with a look of horror on her face. The command "kill (potong)" was shouted at her and again she fell to hacking the raincoat with her knife.

Latah crime is certainly a possibility and may be either: (1) a criminal act resulting from an imperfectly controlled coördinate reaction to a sudden stimulus, as in the case of Amat and of the Malay and Sikh ("a disorder of the intellectual reflexes," as Manson points out); or (2) a criminal act resulting from suppression of volition in the somnambulistic form of latah, the determining cause of which act is a criminal suggestion made by a second party

\section{THE FIRST REPORT ON RESEARCH WORK BY THE DIRECTOR OF WATER EXA- MINATIONS, METROPOLITAN WATER BOARD.}

Dr. A. C. Houston has issued a report upon the vitality of the typhoid bacillus in artificially infected samples of raw Thames, Lea, and New River water, with special reference to the question of storage. The report is of great interest, as the 18 series of experiments carried out with unfiltered waters artificially infected with large numbers of typhoid bacilli, numbers much larger than can be imagined to occur in nature, prove that with no other treatment than simple storage an enormous reduction in the living bacilli occurs. "In practically all the experiments the reduction was over 99.9 per cent. Although from a public health point of view the actual number remaining may be of far greater importance than the percentage reduction, these results show the enormous advantage (in a relative sense, and assuming the possible presence of the typhoid bacillus) 